Jurnal Mahasiswa BK An-Nur : Berbeda, Bermakna, Mulia

Volume 7 Nomor 3 Tahun 2021

Tersedia Online: https://ojs.uniska-bjm.ac.id/index.php/AN-NUR

p-ISSN. 2460-9722 | e-ISSN. 2622-8297

\title{
PENGARUH METODE EDUKASI TERHADAP PENGETAHUAN PASIEN HIV DENGAN ART (ANTIRETROVIRAL THERAPY)
}

\author{
Resti Hapsari Nugrahani ${ }^{1}$, Handayani $^{2}$ \\ ${ }^{1,2}$ Sekolah Pascasarjana Universitas Muhammadiyah Prof Dr. Hamk, Fakultas Ilmu Kesehatan Masyarakat, \\ Jalan Warung Jati Barat, Jakarta Selatan 12740, Indonesia, \\ E-mail : resti.hapsari@gmail.com/085811832381, handayani@uhamka.ac.id /081311247753
}

\begin{abstract}
ABSTRAK
Edukasi adalah kegiatan penyampaian pesan kesehatan kepada kelompok atau individu dengan tujuan dapat memperoleh pengetahuan yang lebih baik. Media edukasi merupakan alat bantu yang berfungsi dalam menjelaskan sebagian ataupun keseluruhan program pembelajaran yang sulit dijelaskan secara verbal. Media yang dipilih dalam penelusuran literature ini adalah audiovisual, dan Buklet. Tujuan: Mengetahui penggunaan media edukasi yang tepat terhadap pengetahuan ODHA terkait gizi. Metode: Jenis penelitian ini adalah penelitian literature review, metode yang digunakan adalah penelusuran database pada PubMed, Google Scholar, dan Research Gate dengan rentang periode publikasi tahun 2010-2021. Hasil: Media edukasi kesehatan yang tepat untuk penderita ODHA terhadap pengetahuan terkait gizi media Buklet. Kesimpulan: Media edukasi yang tepat untuk penderita ODHA yaitu menggunakan media Buklet untuk peningkatan pengetahuan terkait gizi.
\end{abstract}

Kata Kunci: Edukasi; Konseling Gizi; Media Edukasi; ODHA; HIV/AIDS

\begin{abstract}
Education is an activity of delivering health messages to individuals or individuals to obtain better knowledge. Educational media is a tool that explains most of all learning programs that are difficult to solve verbally. The media chosen in this search literature are pocketbooks, leaflets, and audiovisual (video). The media were chosen because they are simple, concise, complete with information and patients can directly ask health officials as well as discuss information delivered. Aims: Knowing the use of appropriate educational media for knowledge to People Live With HIV/AIDS (PLWHIV) about Nutrition. Method: This type of research is a literature review study, The method used is a database search on PubMed, Google Scholar, and Research Gate with a range of years of the publication period 2010-2021. Result: Appropriate health education media for PLWHIV to knowledge are audiovisual, and booklet. Conclusion: The use of educational media for PLWHIV is to use audiovisual, and booklet media and leaflets for diet compliance.
\end{abstract}

Keywords: Education; ounceling; nutrition media, PLWHIV

Dipublikasikan Oleh :

UPT Publikasi dan Pengelolaan Jurnal

Universitas Islam Kalimantan Muhammad Arsyad Al-Banjari Banjarmasin 


\section{Resti Hapsari Nugrahani ${ }^{1}$, Handayani ${ }^{2}$ \\ Jurnal Mahasiswa BK An-Nur : Berbeda, Bermakna, Mulia}

Volume 7 Nomor 3 Tahun 2021

Tersedia Online: https://ojs.uniska-bjm.ac.id/index.php/AN-NUR

p-ISSN. 2460-9722 | e-ISSN. 2622-8297

\section{PENDAHULUAN}

Acquired Immunodeficiency Syndrome (AIDS) adalah infeksi yang disebabkan oleh Human Immunodeficiency Virus (HIV) yang menyebabkan suatu penyakit infeksi yang menyerang sel-sel kekebalan tubuh, terutama sel darah putih yang disebut CD4 sehingga melemahkan kekebalan seseorang terhadap berbagai penyakit infeksi. (WHO, 2020). HIV terus menjadi masalah kesehatan masyarakat global yang utama, telah merenggut hampir 33 juta nyawa. HIV bisa menyerang siapa saja, tanpa memandang umur, jenis kelamin, ras dan sosial. HIV-AIDS dapat menjadi ancaman pada suatu bangsa apabila Negara dan warga negara tidak secara komprehensif dan bersinambung menanggulanginya (WHO, 2020).

Berdasarkan data WHO dalam United Nations Programme on HIV and AIDS (UNAIDS), Populasi kasus HIV-AIDS di dunia mencapai 38 Juta orang, dimana populasi tertinggi adalah di wilayah Benua Afrika yaitu sebesar 25,5 Juta Orang kemudian diikuti.Asia Pasifik sebesar 5,8 Juta orang, Asia Tenggara sendiri memiliki jumlah populasi kasus HIV sebesar 3,8 Juta orang (UNAIDS, 2019). Indonesia merupakan salah satu negara yang memiliki jumlah penduduk terbanyak di Kawasan Asia Tenggara patut untuk lebih waspada terhadap peningkatan tingginya kasus Infeksi HIV.

Peningkatan penggunaan ARV di Indonesia menunjukkan dampak yang cukup signifikan, dengan penurunan angka kematian yang disebabkan oleh HIV dan AIDS (case fatality rate/CFR) . Efektivitas pengobatan ARV sebagai HIV treatment as prevention membuktikan bahwa pengobatan ARV lebih dini memberikan manfaat ganda, yaitu selain menurunkan angka kematian dan meningkatkan kualitas hidup tahun 2014. (Perwira, 2016)

Konsumsi ARV merupakan salah satu faktor yang mungkin berhubungan dengan status gizi pasien HIV/AIDS. Menurut penelitian ada hubungan antara lama terapi Antiretroviral Terapi dengan malnutrisi (Putri, 2017). Malnutrisi adalah tanda khas dari penyakit HIV. Individu pada semua stadium HIV memiliki risiko menjadi malnutrisi dan status gizi menjadi penanda perjalanan penyakit, kualitas hidup, dan surviral rate (Bhowmik et al., 2018) dalam (Hanifa \& Mahmuda, 2020). Keadaan malnutrisi ini dapat menyebabkan turunnya imunitas, meningkatkan resiko untuk terkena infeksi oportunistik, dan mempengaruhi absorbsi obat ARV dalam tubuh.Tahap akhir dari keadaan malnutrisi ini adalah HIV wasting syndrome. Oleh karena itu, status gizi yang buruk pada pasien HIV dapat mempercepat progresivitas penyakit menjadi AIDS, mortalitas yang meningkat dan penurunan waktu harapan hidup.

Kekurangan konsumsi makanan terutama asupan energi dan protein menyebabkan malnutrisi yang dapat mempercepat perkembangan penyakit HIV serta menghambat pengobatan. Penggunaan obat antiretroviral (ARV) tertentu mempunyai efek samping yang dapat diperburuk jika obat dikonsumsi tanpa makanan. dan gizi buruk bisa menghambat kemampuan obat tersebut. Tanpa dukungan asupan zat gizi yang adekuat, stres metabolik akibat infeksi akan menimbulkan kehilangan berat badan dan rusaknya sel bagian tubuh pada organ vital. Indeks massa tubuh (IMT) yang rendah menjadi prediktor independen terhadap mortalitas awal HIV/AIDS (Yuniarti et al., 2013).

Menurut teori Lawrence Green (1980) dalam Notoatmodjo (2014) menerangkan bahwa satu diantara yang mempengaruhi perilaku seseorang atau masyarakat tentang kesehatan ditentukan oleh pengetahuan. Semakin sering seseorang mendapat edukasi, maka semakin baik pula perilakunya (Notoatmodjo, 2014)

Survey yang dilakukan oleh The Nutrition Task Force for HIV (TNT HIV) pada 5 pusat pelayanan kesehatan terhadap 580 ODHA dengan usia rata-rata 37 tahun dihasilkan sebanyak $46 \%$ memiliki pengetahuan yang rendah, $35 \%$ dengan pola makan tinggi $\mathrm{KH}, 62,1 \%$ keamanan makanan rendah, dan $62 \%$ rawan pangan. Berdasarkan hasil survey tersebut dilakukan intervensi bertujuan mencegah dan mengatasi masalah gizi dengan edukasi gizi melalui kelas memasak, nutrition camp, group education, dan konseling individual. (Jantarapakde et al., 2014).

Keefektifan edukasi dan konseling gizi diperkuat dengan hasil penelitian yang menunjukkan bahwa konseling gizi berbasis masyarakat dengan pendidikan gizi yang menekankan pada diit seimbang sesuai budaya dapat membantu meningkatkan pengetahuan dalam mengatasi masalah malnutrisi. Di dalam kegiatan edukasi dan konseling gizi yang efektif tersebut termasuk didalamnya adalah bagaimana penilaian status gizi, pemantauan serta evaluasi selain pendidikan terkait energi dan nutrisi seimbang (Moramarco, 2017). Penelitian lain tentang bagaimana pengaruh konseling nutrisi pada status gizi orang dengan HIV/AIDS menunjukkan hasil bahwa pada orang dengan HIV/AIDS usia dewasa terdapat beberapa faktor yang berkontribusi dalam terjadinya masalah kekurangan

Dipublikasikan Oleh :

UPT Publikasi dan Pengelolaan Jurnal

Universitas Islam Kalimantan Muhammad Arsyad Al-Banjari Banjarmasin 


\section{Resti Hapsari Nugrahani ${ }^{1}$, Handayani ${ }^{2}$ \\ Jurnal Mahasiswa BK An-Nur : Berbeda, Bermakna, Mulia}

Volume 7 Nomor 3 Tahun 2021

Tersedia Online: https://ojs.uniska-bjm.ac.id/index.php/AN-NUR

p-ISSN. 2460-9722 | e-ISSN. 2622-8297

gizi. Beberapa faktor tersebut diantaranya adalah usia yang lebih muda, pendapatan yang rendah, pola makan dan keragaman makanan yang tidak adekuat, serta tidak menerima edukasi dan konseling gizi (Tedla, 2020).

Edukasi gizi bagi penyandang ODHA beserta keluarganya diperlukan untuk mengatasi ketidakpatuhan tersebut karena penyakit HIV/AIDS adalah penyakit yang berhubungan dengan gaya hidup. Hasil penelitian di Uyo, Nigeria Timur menunjukkan adanya perbedaan yang bermakna $(\mathrm{p}<0,05)$ antara kelompok perlakuan dan kontrol terhadap serum protein (status gizi) pada ODHA yang diberi konseling gizi dan suplementasi mikronutrien (Yuniarti et al., 2013). Penelitian lain juga menyebutkan bahwa edukasi dan konseling gizi menggunakan media edukasi yang lebih lengkap dan diberikan secara berkelanjutan dapat meningkatkan pengetahuan (nilai $\mathrm{p}=0,000$ ) dan mengubah perilaku (nilai $\mathrm{p}=0,048$ ) orang yang hidup dengan HIV. (Hudayani \& Sartika, 2016).

\section{METODE}

Desain penelitian yang digunakan adalah literature review. Literatur review merupakan menganalisis, mengevaluasi dan mensintesis adanya temuan teori oleh penelitian sebelumnya. Kerangka kerja pada penelitian ini adalah kerangka kerja PICO. Dengan menggunakan kata kunci "Edukasi dan Konseling Gizi pasien HIV/AIDS" dalam bahasa Indonesia Didapatkan 10 artikel jurnal yang terpilih yang telah melewati eliminasi dan skrining kriteria inklusi dan kriteria ekslusi. Penulis bertanggung jawab atas isi artikel.

\section{HASIL DAN PEMBAHASAN}

Pasien HIV membutuhkan edukasi dengan harapan dapat mengatasi masalah dan meningkatkan kepatuhan pengobatan. Terapi ARV saat ini hanya meningkatkan sistem imun dengan menghambat replikasi virus atau memutuskan rantai reproduksi virus, oleh karena itu, ARV harus diminum setiap hari dan seumur hidup pada pasien HIV, akibatnya sering menimbulkan kebosanan.Namun bukan hanya bosan tetapi masalah efek samping, interaksi efektivitas obat (Fresia, 2017).

Banyak penelitian telah menegaskan bahwa masalah gizi di kalangan ODHA dapat dikelola melalui pemberian pendidikan gizi dan penyuluhan. Integrasi antara pengobatan dan Edukasi juga konseling gizi telah direkomendasikan untuk menjadi efektif cara meningkatkan kualitas hidup ODHA. Edukasi gizi dan konseling dapat membantu individu, keluarga, dan masyarakat ODHA untuk membuat pilihan informasi tentang makanan dan gaya hidup yang mendukung kesehatan fisiologis, ekonomi, dan kesejahteraan sosial mereka. Edukasi dan konseling gizi terbukti efektif dalam memodifikasi praktik pengelolaan pengaturan makan yang memengaruhi penyakit kronis pada ODHA (Fanta, 2014 dalam (Malama \& Ndhlovu, 2019).

Penelitian yang dilakukan pada ODHA terdapat perubahan perilaku yang signifikan setelah menerima edukasi dan konseling gizi. Penelitian ini menunjukkan bahwa edukasi dan konseling gizi menggunakan media edukasi yang lebih lengkap dan diberikan secara berkelanjutan dapat meningkatkan pengetahuan dan mengubah perilaku orang yang hidup dengan HIV. (Hudayani \& Sartika, 2016) Menurut studi penelitian yang dilakukan pada 54 pasien ODHA di RSUPN Dr. Cipto Mangunkusumo bahwa edukasi gizi merupakan langkah yang baik untuk meningkatkan pengetahuan dan membentuk perilaku ODHA agar dapat mengkonsumsi makanan dan minuman bergizi dan cukup aman. (Hudayani et al., 2014).

Penelitian yang dilakukan (Bukusuba, Kikafunda dan Whitehead, 2010) di Uganda terhadap wanita positif HIV, menunjukkan bahwa pemberian pengetahuan mengenai bahan makanan yang bergizi dirasakan efektif dengan pendekatan pengelompokkan bahan makanan. Misalnya kelompok tepung-tepungan, sumber protein, buahbuahan, sayur dan makanan yang sesuai dengan musim. Dengan cara ini dapat meningkatkan pengetahuan ODHA mengenai bahan makanan (pvalue 0,006) dan jadwal makan ( $\mathrm{p}$ value 0,002 ) (Malama \& Ndhlovu, 2019).

Hasil penelitian yang diperoleh (Yuniarti, 2013) bahwa perubahan asupan energi menunjukkan perbedaan bermakna antara kelompok konseling gizi plus (kelompok perlakuan) dan kelompok konseling gizi (kelompok kontrol) $\quad(\mathrm{p}<0,05)$. Hal ini menunjukkan bahwa pemberian konseling gizi plus berpengaruh terhadap asupan energi pada pasien ODHA, Dimana subjek Pendidikan pada penelitian tersebut sebagian besar status pendidikan pasien ODHA adalah SMA $(47,5 \%)$ dan diikuti perguruan tinggi (21,5\%). (Yuniarti et al., 2013).

Dalam media mukasi audiovisual, Pendidikan kesehatan dengan media atau alat peraga dapat mengubah pengetahuan melalui pancaindera yang ditangkap oleh seseorang. Media audiovisual

Dipublikasikan Oleh :

UPT Publikasi dan Pengelolaan Jurnal

Universitas Islam Kalimantan Muhammad Arsyad Al-Banjari Banjarmasin 


\section{Resti Hapsari Nugrahani ${ }^{1}$, Handayani ${ }^{2}$ \\ Jurnal Mahasiswa BK An-Nur : Berbeda, Bermakna, Mulia}

Volume 7 Nomor 3 Tahun 2021

Tersedia Online: https://ojs.uniska-bjm.ac.id/index.php/AN-NUR

p-ISSN. 2460-9722 | e-ISSN. 2622-8297

adalah alat bantu pendidikan yang dalam penggunaannya menstimulasi indera penglihtan dan pendengaran. (Muliawan, 2006). Menurut Arsyad media audiovisual merupakan alat bantu pendidikan yang memiliki unsur suara dan gambar, sifatnya mampu meningkatkan persepsi, mampu meningkatkan pengertian dan meningkatkan ingatan (Arsyad A., 2006). Sedangkan menurut Parwata dalam (Fressia, 2016) media audiovisual adalah media penyampaian informasi yang memiliki karakteristik audio (suara) dan visual (gambar). Jenis media ini mempunyai kemampuan yang lebih baik, karena meliputi kedua karaktersitik tersebut. Tujuan audiovisual adalah salah satu alat untuk menjangkau khalayak tertentu dalam rangka mengkomunikasikan pesan khusus demi mencapai tujuan-tujuan tertentu. (Fresia, 2017)Hasil penelitian Nazarwin (2011) menyatakan bahwa Ada perbedaan pengetahuan yang bermakna antara sebelum dan setelah intervensi pendidikan kesehatan HIV AIDS dengan metode ceramah dengan media audio visual (Pvalue $=0,000)$ (Nazarwin, 2011) Hal ini didukung dengan penelitian yang dilakukan Fresia (2017) yang menyatakan ada perbedaan rata-rata mean kepatuhan edukasi dengan audiovisual (Pvalue $=0,003,95 \% \quad \mathrm{CI}=1,107-3,782$ ) (Fresia, 2017).

Penelitian Nonce (2019) juga menyebutkan bahwa media edukasi menggunakan video merupakan salah satu media penyampai pesan yang dianggap efektif dengan penerimaan pengetahuan yang ada pada seseorang diterima melalui indera. (Nonce et al., 2019). Menurut penelitian para ahli indera yang paling banyak menyalurkan pengetahuan keotak adalah indera pandang. Kurang lebih $75 \%$ sampai $87 \%$ dari pengetahuan manusia disalurkan melalui indera pandang, $13 \%$ melalui indera dengar dan $12 \%$ lainnya tersalur melalui indera yang lain (Tuzzaroh, 2015). Sejalan dengan penelitian Kallo (2018) menyatakan bahwa edukasi kesehatan dengan metode Video sangat efektif dalam peningkatan pengetahuan parapasien DM. Metode yang lebih menarik membantu pasien dalam penyerapan informasi Informasi yang diberikan lewat video juga lebih mudah didapatkan karena para responden bisa melihat kembali edukasi yang diberikan lewat internet sewaktu-waktu jika diperlukan. Metode edukasi yang seperti itu memungkinkan para pasien untuk semakin tertarik dalam mengikuti penyuluhan-penyuluhan kesehatan selanjutnya yang akan diselenggarakan (Kallo \& Masi, 2018).

Dalam media edukasi buklet, menurut Uha, (2003) Buklet merupakan media penyampai pesan kesehatan dalam bentuk media cetak dan atau buku dengan kombinasi tulisan dan gambar. Kelebihan yang dimiliki media buklet yaitu informasi yang dituangkan lebih lengkap, lebih terperinci dan jelas serta bersifat edukatif. Selain itu, buklet yang digunakan sebagai media edukasi ini bisa dibawa pulang, sehingga dapat dibaca berulang dan disimpan. (Safitri, 2016). Didukung oleh pernyataan penelitian bahwa pemahaman jangka panjang pada edukasi yang menggunakan media Buklet akan terjadi dan ketika dilakukan follow up,penerimain formasi akan mengulang dan membaca kembali apa yang ada pada media buklet dan leaflet (Azwar \& Musdalipa, 2020)(Uha, 2003) dalam (Safitri, 2016) menyatakan penyusunan media ini disesuaikan dengan kebutuhan dan kondisi pasien ODHA serta dikombinasikan dengan gambar sehingga menarik perhatian sehingga menghindari kejenuhan dalam membaca. Dalam penelitian Farudin (2011) menyatakan terdapat perbedaan bermakna rata skor pengetahuan pemberian buklet dapat meningkatkan skor pengetahuan dan mengendalikan kadar gula darah dibandingkan leaflet dimana skor pengetahuan diperoleh $p$ value sebesar 0.01(Farudin, 2011).

Dalam Penelitian lain dikatakan edukasi dengan menggunakan media Buklet memiliki peningkatan pengetahun dari kategori kurang $(35,5 \%)$ menjadi baik $(74,2 \%)$, sikap dari kategori baik (80,6\%) menjadi $(93,5 \%)$ (Ovita Mayasari, 2020) Didukung oleh hasil penelitian yang dilakukan di RSUPN Cipto Mangunkusumo yang menyebutkan terdapat meningkatkan pengetahuan (nilai $\mathrm{p}=0,000$ ) dan mengubah perilaku (nilai $\mathrm{p}=0,048$ ) orang yang hidup dengan HI, penelitian ini menggunakan media Buklet sebagai sarana media edukasi yang dianggap lebih lengkap. (Hudayani \& Sartika, 2016). Selain itu media buklet juga dapat dimodifikasi dalam bentuk lain seperti Kartu Gizi atau disebut dalam sebuah program kreativitas mahasiswa "Kargizipdia", metode modifikasi buklet ini diasum mudah dibaca dan disimpan, dalam penelitian test untuk mengetahui efektivitas pemberian pendidikan gizi berdasarkan hasil post test diketahui bahwa nilai rata-rata pengetahuan gizi meningkat dari 54.8 menjadi 58.5 (6\%). Hal tersebut menunjukan bahwa KARGIPEDIA yang diberikan dapat membantu ODHA terutama dalam pemilihan jumlah dan jenis pangan. Menurut ODHA, KARGIPEDIA mudah digunakan serta mudah dibawa-bawa karena bentuknya yang kecil, selain itu KARGIPEDIA juga mudah dimengerti (Cita et al., 2014).

Media edukasi merupakan alat atau bahan

Dipublikasikan Oleh :

UPT Publikasi dan Pengelolaan Jurnal

Universitas Islam Kalimantan Muhammad Arsyad Al-Banjari Banjarmasin 


\section{Resti Hapsari Nugrahani ${ }^{1}$, Handayani ${ }^{2}$ \\ Jurnal Mahasiswa BK An-Nur : Berbeda, Bermakna, Mulia \\ Volume 7 Nomor 3 Tahun 2021 \\ Tersedia Online: https://ojs.uniska-bjm.ac.id/index.php/AN-NUR \\ p-ISSN. 2460-9722 | e-ISSN. 2622-8297}

yang digunakan sebagai media untuk pesan yang disampaikan dengan tujuan untuk lebih mudah memperjelas pesan, atau untuk lebih memperluas jangkauan pesan. Penggunaan media bertujuan untuk memaksimalkan indera yang ada dalam menangkap pesan (Hidayah \& Sopiyandi, 2019). Pengetahuan yang diberikan melalui indera penglihatan ialah $75 \%$ sampai $87 \%$, melalui indera pendengaran ialah $13 \%$, dan $12 \%$ dari indera yang lain. Semakin banyak indera dilibatkan dalam penangkapan pesan, maka semakin mudah pesan dapat diterima oleh sasaran pendidikan. Media edukasi kesehatan dapat berupa media cetak dan media elektronik (Notoatmodjo, 2014).

Menurut teori Lawrence Green (1980) dalam Notoatmodjo (2010) menerangkan bahwa satu diantara yang mempengaruhi perilaku seseorang atau masyarakat tentang kesehatan ditentukan oleh pengetahuan. Semakin sering seseorang mendapat edukasi, maka semakin baik pula perilakunya (Restuning, 2015)Hasil penelitian Hudayani (2016) tentang pengetahuan gizi pada terhadap 25 ODHA pada kelompok perlakuan didapatkan hasil 18 orang (72\%) berada pada pendidikan Sekolah Menengah Atas (SMA) dan dari 29 ODHA dari kelompok kontrol terdapat 19 orang $(65,5 \%)$ dari Pendidikan SMA. (Hudayani et al., 2014).

Hal ini menunjukkan Semakin tinggi tingkat pendidikan maka semakin besar pengetahuan dan semakin mudah mengembangkan pengetahuan yang berdampak pada peningkatan kesejahteraan seseorang. Pendidikan menjadi penting karena memengaruhi pola pikir seseorang tentang sesuatu hal sehingga berpengaruh dalam pengambilan suatu keputusan. (Notoatmodjo, 2014).

Menurut (Anya, 2002) HIV menyebabkan hilangnya nafsu makan dan gangguan penyerapan nutrient. Hal ini berhubungan dengan menurunnya atau habisnya cadangan vitamin dan mineral dalam tubuh. Defisiensi vitamin dan mineral pada ODHA dimulai sejak masih stadium dini. Walaupun jumlah makanan di tempat pelayanan Kesehatan yang melayani ODHA sudah cukup dan berimbang seperti orang sehat, tetapi akan tetap terjadi defisiensi vitamin dan mineral (Nursalam \& Dian, 2007) Selain itu menurut Enwonwu (2006) di Nigeria menyebutkan bahwa Infeksi HIV mempengaruhi status gizi akibat berkurangnya asupan makanan yang disebabkan oleh hilangnya nafsu makan, efek samping obat, dan infeksi oportunistik seperti diare kronik, kandidiasis orofaringealdan limfadenopati. (Sofro et al., 2013).

Maka dari itu Informasi yang sangat diperlukan yaitu informasi terkait pesan tentang penyampaian kesehatan terkait kepatuhan diet gizi seimbang pada ODHA, diantaranya penyampaian informasi yang dapat dilakukan oleh perawat adalah penyuluhan atau edukasi kesehatan dengan menggunakan media. Media yang sering digunakan untuk penyampaian pendidikan kesehatan atau edukasi yaitu berupa media leaflet dengan metode ceramah atau diskusi dan audiovisual (Khasanah \& Fitri, 2019)Menurut Tomastola (2015) bahwa penyediaan bahan edukasi yang informatif dan menarik merupakan pendukung yang sangat kuat didalam memberikan penyuluhan kesehatan karena dengan cepat akan meningkatkan pengetahuan. Media dalam penelitian ini yang digunakan adalah buku saku dipilih karena ukurannya yang kecil, ringan, bisa disimpan disaku, sehingga praktis untuk dibawa kemana-mana, dan kapan saja bisa dibaca (Tomastola et al., 2015).

Sejalan dengan penelitian yang dilakukan oleh Eliana dan Sholikhah (2013) terjadi perubahan pengetahuan sesudah diberikan edukasi dengan media buku saku. Pada variabel pengetahuan menunjukkan bahwa ada perbedaan yang signifikan antara pengetahuan responden dengan pemberian edukasi gizi melalui media buku saku dan media buklet. Pada saat edukasi responden kedua kelompok mendengarkan dengan baik apa yang disampaikan oleh pemberi informasi menggunakan buku saku dan buklet. Hal ini sesuai dengan teori bahwa media edukasi dapat menciptakan kondisi tertentu sehingga memungkinkan responden memperoleh pengetahuan, keterampilan atau sikap yang baru (Supariasa, 2013).

Media pendidikan kesehatan disebut juga sebagai alat peraga. Media yang dapat digunakan yaitu dengan alat bantu lihat dengar (Audio Visual Aids). Alat bantu audio visual adalah alat yang digunakan oleh pembicara materi dalam menyampaikan pesan kesehatan melalui alat bantu lihat dengar, seperti video, film dan lain-lain (Induniasih \& Wahyu, 2019). Pada penelitian yang dilakukan Nonce (2019) menyatakan sebagian besar pengetahuan responden mengalami peningkatan setelah diberikan konseling gizi dengan menggunakan video makanan yaitu sebesar $64.7 \%$. Peningkatan pengetahuan dapat mempengaruhi tingkat kepatuhan diet pasien (Nonce et al., 2019). Audiovisual merupakan media yang menarik, alat bantu pendidikan yang penggunaanyamenstlimulasi indra pendengaran dan penglihatan, dapat diputar berulang-ulang (Supariasa, 2013); (Lamatenggo \& Uno, 2016). Pada penelitian ini peningkatan skore

Dipublikasikan Oleh :

UPT Publikasi dan Pengelolaan Jurnal

Universitas Islam Kalimantan Muhammad Arsyad Al-Banjari Banjarmasin 


\section{Resti Hapsari Nugrahani ${ }^{1}$, Handayani ${ }^{2}$ \\ Jurnal Mahasiswa BK An-Nur : Berbeda, Bermakna, Mulia}

Volume 7 Nomor 3 Tahun 2021

Tersedia Online: https://ojs.uniska-bjm.ac.id/index.php/AN-NUR

p-ISSN. 2460-9722 | e-ISSN. 2622-8297

sikap bahwa dengan adanya media video yang berdurasi 10 menit efektif untuk meningkatkan sikap, durasi video akan mempengaruhi seseorang dalam ketertarikan dan menyerapan informasi. Semakin lama pemutaran video ketertarikan seseorang akan semakin menurun (Guo et al., 2014).

Media yang tidak kalah menariknya adalah media Buklet. Buklet walapun termasuk media cetak merupakan media yang menarik, Buklet merupakan sebuah media pembelajaran yang menyampaikan pesan kesehatan dalam bentuk buku yang berisi tulisan dan gambar, yang terdiri dari tidak lebih dari 24 halaman, merupakan media yang menarik karena dapat menstimulasi indra penglihatan sehingga lebih mudah dalam penyampaian informasi dan dapat dibaca sewaktu-waktu serta mudah untuk di bawa kemana-mana (Supariasa, 2013);(Lamatenggo \& Uno, 2016) Hasil penelitian ini sesuai dengan penelitian yang dilakukan Kumboyono (2011) perbedaan efek penyuluhan dengan menggunakan media cetak dan media audiovisual terhadap peningkatan pengetahuan pada penderita tuberculosis (Kumboyono, 2011), yang banyak terjadi pada ODHA. Penelitian yang dilakuakn oleh Purniawan (2016) pendidikan kesehatan dengan menggunakan media yang bersamaan yaitu media cetak poster dan video dapat meningkatkan pengetahuan ibu tentang TB paru dan pencegahannya. Berdasarkan hasil penelitian dan teori diatas bahwa pendidikan kesehatan dapat meningkatkan sikap maupun perilaku. Sikap secara nyata menunjukkan reaksi terhadap kesesuaian stimulus dalam kehidupan sehari-hari, sikap merupakan kesediaan untuk bertindak dan bukan merupakan pelaksanaan tindakan, Semakin tinggi pengetahuan, semakin tinggi pula sikap yang baik akan terbentuk akan tetapi sikap merupakan predisposisi dari munculnya Tindakan.

\section{PENUTUP}

Dari hasil analisa diatas diketahui bahwa sebagian besar penderita ODHA menerima edukasi kesehatan media Buklet untuk pengetahuannya, baik dari segi penampilan maupun isi pesan. Hasil yang didapatkan ada peningkatan pengetahuan ODHA terkait pola makannya antara sebelum dan setelah pemberian edukasi kesehatan media Buklet. Diharapkan petugas kesehatan dapat memberikan inovasi edukasi kesehatan terkait penyakit yang diderita lebih menarik dalam penyampaian media edukasi yang digunakan. Media edukasi kesehatan tentang kepatuhan diet merujuk ke semua pasien
ODHA yang dirawat inap maupun rawat jalan untuk mendapatkan penjelasan tentang pengelolaan makanan bergizi seimbang untuk meningkatkan dan mempertahankan status gizi yang baik. Untuk peneliti selanjutnya diharapkan mampu mengembangkan metode penelusuran web pencarian artikel. Penambahan referensi terhadap media apa saja yang lebih inovatif serta sangat berpengaruh dalam penyampaian edukasi kesehatan.

\section{REFERENSI}

Arsyad A. (2006). Media Pembelajaran. PT. Raja Grafindo Persada.

Azwar, A., \& Musdalipa, M. (2020). Media Booklet dan Leaflet sebagai Upaya Pencegahan Stunting: Kajian literatur (A Literature Review). Community, Family, and Gerontological Nursing Journal, 1(1), 29-36. (Buku)

Cita, D. A., Wijaya, D., Wardah, S. H., Hasanah, F. A., \& Oktaviana, M. (2014). Kartu gizi pedia "kargipedia" sebagai solusi efektif peningkatan pengetahuan gizi dalam upaya optimalisasi kesehatan orang dengan hiv aids (odha).

Farudin, A. (2011). Perbedaan Efek Konseling Gizi Dengan Media Leaflet Dan Booklet Terhadap Tingkat Pengetahuan, Asupan Energi Dan Kadar Gula Darah Pada Pasien Diabetes Melitus Di Rsud Dr. Moewardi Surakarta.

Fresia, S. (2017). Efektivitas Pemberian Edukasi Berbasis Audiovisual dan Tutorial Tentang Antiretroviral (ARV) Terhadap Kepatuhan Pengobatan pada Pasien HIV/AIDS di Klinik Teratai Rumah Sakit Hasan Sadikin Bandung Tahun 2016. The Indonesian Journal of Infectious Diseases, 3(2), 38-45.

Guo, P. J., Kim, J., \& Rubin, R. (2014). How video production affects student engagement: An empirical study of MOOC videos. Proceedings of the First ACM Conference on Learning@ Scale Conference, 41-50.

Hidayah, M., \& Sopiyandi. (2019). Efektifitas Penggunaan Media Edukasi Buku Saku Dan Leaflet Terhadap Pengetahuan Dan Kepatuhan Diet Pasien Rawat Jalan Diabetes Melitus Tipe 2 Di Puskesmas. Pontianak Nutrition Journal (PNJ), 1(2), 66-69

Hudayani, F., \& Sartika, R. A. D. (2016). Knowledge and behavior change of people living with HIV through nutrition education and counseling. Kesmas: Jurnal Kesehatan Masyarakat

Dipublikasikan Oleh :

UPT Publikasi dan Pengelolaan Jurnal

Universitas Islam Kalimantan Muhammad Arsyad Al-Banjari Banjarmasin 
Resti Hapsari Nugrahani ${ }^{1}$, Handayani ${ }^{2}$

Jurnal Mahasiswa BK An-Nur : Berbeda, Bermakna, Mulia

Volume 7 Nomor 3 Tahun 2021

Tersedia Online: https://ojs.uniska-bjm.ac.id/index.php/AN-NUR

p-ISSN. 2460-9722 | e-ISSN. 2622-8297

Nasional (National Public Health Journal), 10(3), 107-112 https://doi.org/10.33096/woph.v1i5.158

Hudayani, F., Sartika, R. A. D., Djokosujono, K., Hassan, A., Kresnawan, T., \& Rachmadi, K. (2014). Pengaruh pemberian edukasi dan konseling gizi terhadap pengetahuan sikap perilaku dan berat badan odha di UPT HIV RSUPN DR Cipto Mangunkusumo Jakarta tahun 2014= Effect of nutrition education and counseling on knowledge attitude behavior and body weight plwha in hiv integrated care unit RSUPN DR Cipto Mangunkusumo Jakarta 2014.

Induniasih, I., \& Wahyu, R. (2019). Promosi kesehatan: pendidikan kesehatan dalam keperawatan

Jantarapakde, J., Phanuphak, N., Chaturawit, C., Pengnonyang, S., Mathajittiphan, P., Takamtha, P., Dungjun, N., Pinyakorn, S., Pima, W., \& Prasithsirikul, W. (2014). Prevalence of metabolic syndrome among antiretroviral-naive and antiretroviralexperienced HIV-1 infected Thai adults. AIDS Patient Care and STDs, 28(7), 331-340.

Kallo, V., \& Masi, G. (2018). Efektifitas Pemberian Edukasi Dengan Metode Video Dan Focus Group Discussion (Fgd) Terhadap Tingkat Pengetahuan Pasien Dm Tipe 2 Di Klinikdiabetes Kimia Farma Husada Manado. Jurnal Keperawatan, 6(1)

Khasanah, T. A., \& Fitri, Z. F. (2019). Hubungan Pengetahuan dan Kepatuhan Diet dengan Kadar Gula Darah pada pasien Diabetes Melitus Di Poli Penyakit Dalam RSUD Idaman Banjarbaru Tahun 2018. Jurnal Kesehatan Indonesia, 9(2), 84-90.

Kumboyono. (2011). Perbedaan Efek Penyuluhan Kesehatan MenggunakanMedia Cetak Dengan Media Audio Visual Terhadap Peningkatan Pengetahuan Pasien Tuberculosis. Jurnal Ilmu Kesehatan Keperawatan, 7(1).

Lamatenggo, N., \& Uno, H. B. (2016). Teknologi komunikasi \& informasi pembelajaran. Bumi Aksara.

Malama, E., \& Ndhlovu, D. (2019). Nutrition Education, Counselling and Assessment Support Approach for People Living with HIV and AIDS: A Literature Review. International Journal of Contemporary Applied Researches.

Moramarco, S. , \& B. E. (2017).

Nutritional Counseling Improves Dietary Di versity andFeeding Habits of Zambian Maln ourished Children Admitted in Rainbow

Nutritional Programs. Biomedicine and

Prevention,70-76.

http://dx.doi.org/10.19252/00000005D

Muliawan, B. T. (2006). Pelayanan Konseling Akan Meningkatkan Kepatuhan Pasien Pada Terapi Obat. www.depkes.go.id

Nazarwin, S. (2011). Perbedaan pengaruh pendidikan kesehatan HIV AIDS dengan metode curah pendapat dan ceramah menggunakan media audio visual terhadap pengetahuan siswa SMAN 4 Tangerang Selatan.

Nonce, L. N., Pasambuna, M., Purba, R. B., \& Kasiati, O. (2019). Media video makanan terhadap pengetahuan dan kepatuhan diet serta pengendalian kadar glukosa darah pasien diabetes melitus tipe II. Jurnal GIZIDO, 11(2), 81-87.

Notoatmodjo. (2014). Promosi Kesehatan dan Perilaku Kesehatan. Rineka Cipta.

Nursalam, D. K., \& Dian, N. (2007). Asuhan keperawatan pada pasien terinfeksi HIV. Jakarta: Salemba Medika. (Buku)

Ovita Mayasari. (2020). Perbedaan Pengaruh Media Promosi Kesehatan Booklet dengan Audiovisual Terhadap Pengetahuan dan Sikap Calon Pengantin Tentang Pencegahan Penularan HIVI AIDS di Kantor Urusan Agama Semarang Utara, Tahun 2018.

Perwira, I. (2016). Kebijakan dan Program HIV \& AIDS dalam Sistem Kesehatan di Indonesia (Pusat Kebijakan dan Manajemen Kesehatan Fakultas Kedokteran Universitas Gadjah Mada, Ed.).

Putri, C. L. L. F. (2017). Hubungan Lama Terapi Antiretroviral dan Infeksi Oportunistik Terhadap Malnutrisi Pada Pasien HIV/AIDS di RSUDZA Banda Aceh. ETD Unsyiah.

Restuning, D. (2015). Efektifitas edukasi diabetes dalam meningkatkan kepatuhan pengaturan diet pada diabetes melitus tipe 2. Mutiara Medika: Jurnal Kedokteran Dan Kesehatan, 15(1), 37-41.

Safitri, N. R. D. and F. D. Y. (2016). PENGARUH EDUKASI GIZI DENGAN CERAMAH DAN BOOKLET TERHADAP PENINGKATAN PENGETAHUAN DAN SIKAP GIZI REMAJA OVERWEIGHT. (Artikel Nasional)

Sofro, M., Angita, I., \& Isbandrio, B. (2013). Karakteristik Pasien HIV/AIDS dengan Kandidiasis Orofaringeal di RSUP Dr. Kariadi

Dipublikasikan Oleh :

UPT Publikasi dan Pengelolaan Jurnal

Universitas Islam Kalimantan Muhammad Arsyad Al-Banjari Banjarmasin 
Resti Hapsari Nugrahani ${ }^{1}$, Handayani ${ }^{2}$

Jurnal Mahasiswa BK An-Nur : Berbeda, Bermakna, Mulia

Volume 7 Nomor 3 Tahun 2021

Tersedia Online: https://ojs.uniska-bjm.ac.id/index.php/AN-NUR

p-ISSN. 2460-9722 | e-ISSN. 2622-8297

Semarang. Medica Hospitalia: Journal of Clinical Medicine, 1(3). (Artikel Nasional)

Supariasa, N. I. (2013). Pendidikan \& Konsultasi gizi. . EGC. (Buku)

Tedla, W. H. , A. A. , G. K. , A. M. W. , \& W. H. G. (2020). Reducing Undernutrition Through Counseling on Diversified Food Intake among Adult People Living with HIV on HAART, Northern Ethiopia. Journal of Nutrition and Metabolism, 1-10. https://doi.org/10.1155/2020/9858619.

\section{(Artikel Internasional)}

Tomastola, Y. A., Mbonohu, S., \& Barangmanise, S. (2015). Tanggapan Pasien Diabetes Melitus Komplikasi Tentang Penggunaan Media Leaflet Dan Foto Bahan Makanan Pada Konseling Gizi Di Poli Gizi RSUP Prof. Dr. RD Kandou Manado. Jurnal GIZIDO, 7(1). (Artikel Nasional)

Tuzzaroh. (2015). Pengaruh penyuluhan gizi seimbang dengan media video, poster dan permainan kwartet gizi terhadap pengetahuan gizi dan status gizi siswa disekolah dasar negeri karangasem III kota Surakarta. Jurnal Keperawatan. http://eprints.ums.ac.id/id/eprint/39 769. (Artikel Nasional)

UNAIDS. (2019). AIDS DATA. AIDS INFO. (Laporan / report)

WHO. (2020). HIV/AIDS. 2020. https://www.who.int/health-topics/hivaids\#tab=tab_1

Yuniarti, Y., Purba, M. B., \& Pangastuti, R. (2013). Pengaruh konseling gizi dan penambahan makanan terhadap asupan zat gizi dan status gizi pasien HIV/AIDS. Jurnal Gizi Klinik Indonesia, 9(3), 132-138. (Artikel Nasional)

Dipublikasikan Oleh :

UPT Publikasi dan Pengelolaan Jurnal

Universitas Islam Kalimantan Muhammad Arsyad Al-Banjari Banjarmasin 